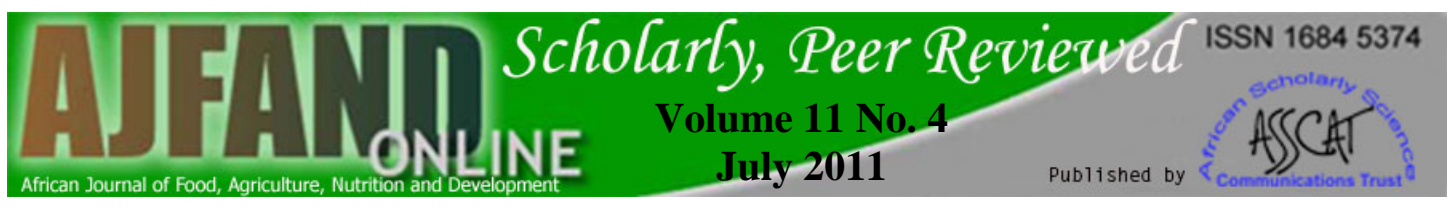

\title{
NUTRIENT-ENHANCEMENT OFMATOOKE BANANA FOR IMPROVED NUTRIENT INTAKE OF PEOPLE LIVING WITH HIV/AIDS IN RAKAI DISTRICT, UGANDA
}

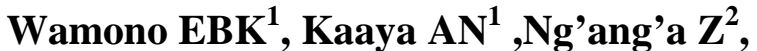 \\ Wamue $G^{3}$, Manyama $A^{4}$, Mwangi $M^{5}$ and $\mathrm{JH}$ Muyonga $^{{ }^{*}}$
}

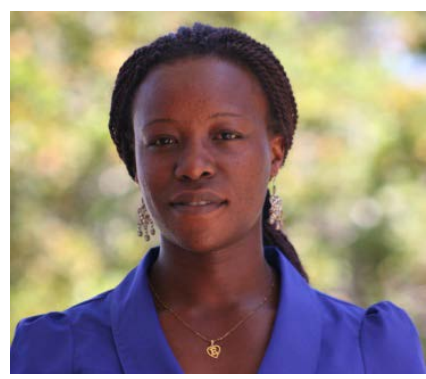

Esther Wamono

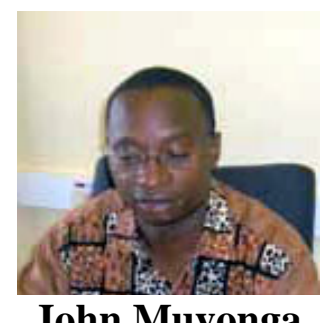

*Corresponding author email:hmuyonga@yahoo.com

${ }^{1}$ School of Food Technology, Nutrition \& Bio-Engineering, Makerere University, P.O. Box 7062, Kampala, Uganda

${ }^{2}$ Institute of Tropical Medicine and Infectious Diseases, Jomo Kenyatta University of Agriculture \& Technology, P.O. Box 6200-00200 Nairobi, Kenya

${ }^{3}$ Department of Gender and Development Studies, Kenyatta University, P.O. Box 62137-00200 Nairobi, Kenya

${ }^{4}$ Department of Agricultural Economics and Agribusiness, Sokoine University of Agriculture, P.O. Box P.O. Box 3007, Morogoro, Tanzania

${ }^{5}$ Department of Biochemistry, Kenyatta University P.O. Box 62137-00200, Nairobi, Kenya. 


\section{ABSTRACT}

The prevalence of HIV in Rakai district is estimated at $12.7 \%$, which is approximately double the national prevalence. It is well established that HIV and AIDS affect nutritional status and food security of populations. The aim of this study was to assess the food and nutrition security of people living with HIV (PLHIV) and the potential of banana nutrient enhancement to improve nutrient intake. A total of 173 PLHIV registered with Rakai Health Science Project were chosen and interviewed using structured questionnaires to determine the current contribution of banana to the household food security. Nutrient intake data were collected using Gibson's 24-hour recall method and food frequency questionnaires. Key informants' interviews with agricultural extension staff and focus group discussions with PLHIV and support group personnel were used to collect qualitative and quantitative information. Experiments were conducted to determine the suitability of banana as a food vehicle to boost the energy and nutrient intake of PLHIV. A product was made by blending banana flour with soybean flour and multi-nutrient fortificant premix. The formulation was reached using the Pearson's square method, with a target protein content of $15 \%$. To pilot test the product, the nutrient-enhanced banana powder was distributed to15 PLHIV and data on acceptability and the contribution of the product to nutrient intake were assessed. It was found that the majority of PLHIV (88\%) in Rakai district consumed banana at least 3 times a week. The baseline daily intake was found to be $1676.2 \mathrm{kcal}, 0.8 \mathrm{mg}, 0.8 \mathrm{mg}, 249.6 \mathrm{mcg}, 259.4 \mathrm{mg}$ and $12.9 \mathrm{mg}$ for energy, vitamin $B_{1}$, vitamin $B_{2}$, folate, calcium and iron respectively, which was below the recommended daily allowances (RDA) for PLHIV. The formulated banana product was found to supply $459.7 \mathrm{kcal}$ and contained $15 \%$ protein. The product was well accepted by the PLHIV and its average level of consumption was $67 \mathrm{~g}$ per day. At this intake level of the product, study households intake of energy, vitamin $\mathrm{B}_{2}$, folate and calcium increased to $1732.89 \mathrm{kcal}, 1.09 \mathrm{mg}, 277.8 \mathrm{mcg}$ and $300.79 \mathrm{mg}$ respectively while iron and vitamin $\mathrm{B}_{1}$ intakes were not significantly different from the baseline values. It can be concluded that supplementation of diet of PLHIV in Rakai with nutrient-enhanced flour can raise nutrient intake of PLHIV to recommended levels for improved nutritional and health status.

Key words: Matooke, HIV/AIDS, malnutrition, energy intake 


\section{INTRODUCTION}

The HIV/AIDS pandemic is one of the most serious health problems in Uganda and it has had an unparalleled negative impact on nutrition, food security, agricultural production and livelihoods of millions of people in the country [1]. The HIV/AIDS prevalence in Uganda is estimated at 6.7\% with the productive age group of 15 to 49 years being the most affected [1]. The pandemic has had devastating effects on household food security and general livelihoods of affected families, especially among resource constrained communities. Rakai district, where the first AIDS case in Uganda was identified in 1982 has an HIV prevalence of $12.7 \%$. Rakai also suffers high rates of malnutrition resulting from a number of factors including poverty, illiteracy, big family sizes, and the effects of the HIV/AIDS pandemic [2, 3].

Nutrition and HIV are linked. Immune impairment by HIV/AIDS contributes to malnutrition through increased resting energy expenditure, reduction in food intake, nutrient loss and mal-absorption, as well as complex metabolic alterations that culminate in weight loss [4]. Malnutrition, on the other hand, leads to immunity impairment, worsens the effects of HIV, and contributes to a more rapid progression of the disease.

People living with HIV/AIDS (PLHIV), therefore, require additional energy to meet elevated needs due to infections and changed metabolism [4]. People living with HIV with symptoms require between $20-30 \%$ more energy per day compared to someone without HIV. The additional energy is required to meet the elevated needs due to infections and changed metabolism. Those who do not have symptoms require $10 \%$ more energy above those of un-infected individuals of same sex, age, physiological status and activity. Proteins should provide $12-15 \%$ of the energy to PLHIV, which is similar to HIV negative people. While it is believed that PLHIV do not require additional micronutrients above those of persons without HIV, low plasma levels of vitamins $\mathrm{A}, \mathrm{E}, \mathrm{B}_{1}, \mathrm{~B}_{2}, \mathrm{~B}_{6}, \mathrm{~B}_{12}, \mathrm{C}, \mathrm{E}$, folic acid, beta carotene and the minerals selenium, iron and zinc are common among PLHIV and contribute to the pathogenesis of HIV infection as well as compromised immunity [4, 5, 6]

Evidence has shown important links between improved HIV and AIDS outcomes and nutrition [7]. Adequate nutrition is necessary to maintain the immune system, manage opportunistic infections, optimize response to medical treatment, sustain healthy levels of physical activity, and support optimal quality of life for PLHIV. Basic micronutrient needs can be met through a diverse diet, fortified foods or micronutrient supplements $[8,9,10]$.

Bananas, especially matooke, form a major part of the diet of people of Rakai district. They are usually consumed as a single staple food often accompanied with nutritionally deficient stews and yet bananas are very inadequate in several essential nutrients [11, 12, 13]. Processing technologies such as extrusion, pre-dehydration cooking and re-hydration and blending have been demonstrated to improve the nutrient density and digestibility of bananas [12, 14, 15]. A combination of the 


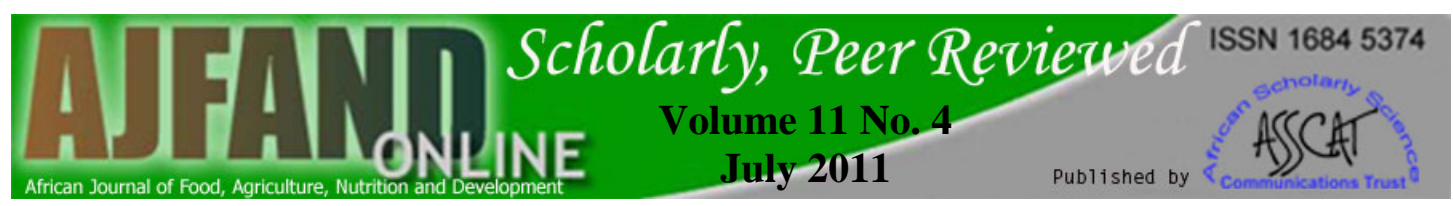

solubilised banana flours with high protein mixes including soybean has been recommended for vulnerable groups [14].

\section{METHODOLOGY}

\section{Study area}

The study was conducted in Rakai district located in the central region of Uganda. The district is divided into three counties: Kakuuto, Kooki and Kyotera which comprise a total of 106,685 households, an average household size of 4.4 and a total population of 470,365 [16]. About 60,000 of the district's total population are PLHIV. This represents $12.7 \%$ of the district's population.

\section{Study design}

The study was descriptive and experimental in nature. A survey was conducted to assess the contribution of bananas to the household food and nutrition security of PLHIV. A 24 hour recall questionnaire, food frequency and food security questionnaires were used to collect quantitative data while focused group discussions (FGD) and key informant interviews were used to collect the qualitative information [17].

\section{Study population and sampling criteria}

The sample size was determined according to Bryan with p as 0.127 (the prevalence of HIV in the district), a confidence interval of $95 \%$, an acceptable error of 0.05 and a confidence level test statistic of 1.96 [18]. A representative sample size of 173 households with at least one PLHIV attached to Rakai Health Science Project (RHSP) was used. Respondents were drawn from 4 sub-counties selected from all the 3 counties making up the district. The sub-counties selected were Kyotera Town from Kyotera county, Kyebe from Kakuuto county, Dwaniro and Lwanda from Kooki county. Kyotera town is a trading centre along a major road. Prevalence of HIV/AIDS in Kyotera is expected to be high due to frequent high-risk sexual behaviours and migration in response to food insecurity and poverty [7]. Dwaniro, Lwanda and Kyebe have very high production of matooke. The clients whose households were to be included in the study were selected systematically from the list of PLHIV registered with the Rakai Health Science Project.

\section{Determination of food consumption patterns}

Dietary intake, food frequency and counts of food groups consumed over the 24-hour period preceding the study were determined. The study used a simple count of food groups consumed in the previous 24-hour period. Twelve food groups were included as recommended by FANTA [19]. In addition, banana was included as a separate food group. The categories therefore were: 1) Cereals, 2) Meat and meat products and eggs 3) Roots and tubers, 4) Vegetables, 5) Fruits, 6) Beans and other pulses, 7) Dairy products, 8) Fats and oil, 9) Sugars and honey, 10) Fish 11) Spices and other products 12) Beverages 13) Bananas. The types of bananas grown and their uses in the households of PLHIV were also determined using a food security questionnaire. 


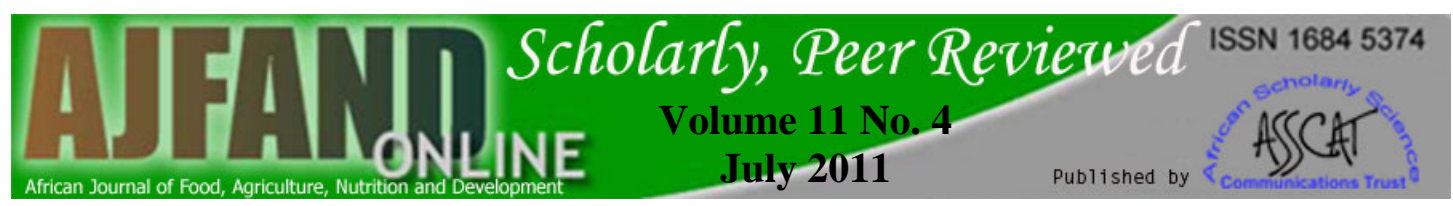

The weights and volumes of foods consumed by the PLHIV in the preceding 24 hour period were established through 24 hour recall interviews [17]. The foods and drinks taken in and outside the household by the subject were all considered in the estimation of the caloric and nutrient provision at the household level. The amounts served, consumed and wasted were also recorded for purposes of estimating the actual amount consumed.

\section{Banana processing and nutrient-enhancement}

Kibuzi, the most popular cooking banana type in Rakai, was used for banana flour processing. Bunches of fully mature and undamaged kibuzi were purchased from suppliers in Kawanda and were processed into flour. The average weight of the big bunches of kibuzi was $30 \mathrm{~kg}$. Each bunch had an average of ten clusters of about 20 fingers each. The banana fingers were detached, washed and steamed traditionally for 40 minutes by covering with banana leaves without peeling. Steaming was chosen because it does not entail immersing the banana into water and it preserves the natural flavour [15]. The loosened peels were stripped off the warm steamed banana fingers by hand. The bananas were then sliced and sun-dried for 48 hours. The average flour yield based on finger weight of banana was $2.45 \%$. The dried banana was milled to pass through a 1mm screen (Cadmach, Machinery Co. Pvt., Ltd., Ahmedabad, India). Newly harvested soybean grains were purchased from Nakasero market, Kampala for protein supplementation to the banana flour. Soybeans were chosen because of their high protein content, high protein digestibility and immunity boosting benefits [20]. The soybean grains were roasted at $130^{\circ} \mathrm{C}$ in a laboratory oven (Thelco, Precision Scientific Inc., Chicago, U.S.A.) for 30 minutes before milling into fine flour. Roasting was chosen because it is known to significantly reduce trypsin inhibitor activity and phytic acid levels and to only moderately increase tannins compared to other cooking methods [21].

Using the Pearson square, the amounts of soy and banana flour to blend together to obtain $15 \%$ protein content in the flour blend were determined as $61 \%$ banana flour and 39\% soy flour [22]. The upper limit of the RDA for protein (15\%) was chosen to avoid supply of excessive protein. For each batch, a total of $27 \mathrm{~kg}$ of banana flour were mixed with $17 \mathrm{~kg}$ of soy flour to obtain $44 \mathrm{~kg}$ of banana-soy blend. The flour was mixed in a clean plastic drum, with a capacity of $135 \mathrm{~L}$ by rolling on the ground for two and a half hours and turning up-side-down twenty-five times. A premix (E/Covit 27272, DARCOF, Denmark) containing vitamin $A, B_{1}, B_{2}, B_{6}$, folic acid, niacin, iron and zinc was added at the recommended dosing level of $20 \mathrm{~g} / 100 \mathrm{~kg}$ of flour. The premix was initially mixed in a small portion $(1 \mathrm{~kg})$ of the banana-soy blend using an electric mixer (Varimixer Bear, Wodschow and Company, Copenhagen, Denmark) for five minutes at a medium speed of the appliance. The procedure was repeated by dividing the mixture of banana-soy and fortificant into three equal portions which were each mixed with $1 \mathrm{~kg}$ of non-fortified banana-soy blend using the Varimixer. Finally, the blend containing the fortificant was mixed into the bulk of the flour in plastic drums by repeated rolling and vertical shaking. To ascertain the uniformity of fortification of the banana-soy blend, samples of the flour were drawn from the top, bottom and side of the drum and analyzed for iron levels. 


\section{Determining the composition of the nutrient-enhanced banana flour}

The total carbohydrate, crude protein, fat and moisture contents of the banana-soy blend were determined using AOAC method [23]. Moisture content, total ash, crude fat, crude fibre, total carbohydrates and crude protein were determined by oven method, hot furnace, Soxhlet, Van soest, spectrophotometric and Kjeldahl ( $\mathrm{N}$ x 6.25) methods respectively. The energy content of the banana-soy blend was determined using bomb calorimeter (CBA301, ABIC, Gallenkamp, United Kingdom).

\section{Sensory evaluation and pre-testing of the nutrient-enhanced banana flour}

Sensory evaluation and pre-testing of the nutrient enhanced banana flour was done among PLHIV in Kyotera County, Rakai district. Fifteen women, which is the minimum number to obtain the desired level of power of intervention, were selected and each supplied with 3kg of the nutrient-enhanced banana flour [24]. The selected PLHIVs were informed of the nutritional composition of the flour and encouraged to use the product in various ways (as a beverage, in porridge, sauce, to add to usual stews and any other forms) depending on their preference. They were also instructed to use a tablespoon to measure the banana product each time it was used and to keep a record of the amounts used.

The study subjects were left to experiment with the nutrient enhanced banana product for three days. Thereafter, they were again interviewed using the 24 hour recall. All the foods consumed in the 24 hours prior to the interviews including the banana product were recorded.

\section{Data analysis}

Nutrient intakes by PLHIV were estimated using the Nutrisis- version 4.02, USDA HealtheTech SR Search 20 [25]. Nutrient adequacies were based on the Recommended Daily Allowances (RDA) for respective age and sex. For nutrients where a range was given, the lower limit was used. The SPSS (version 12.0) package and Windows Excel 2007 were also used to analyze the quantitative and qualitative data on banana consumption levels, uses of bananas in households, banana variety preferences and the contribution of banana in the dietary intake. Concerning food security, average figures for each indicator were determined under the classification of never, rarely, sometimes, often and always and the percentage of never was grouped as food secure, rarely and sometimes as moderately food insecure and often and always as severely food insecure.

\section{RESULTS}

\section{Food composition}

Baseline results showed that $85 \%$ of the households had eaten banana the day before the interviews and only 15\% had not. Most (61\%) of the households had eaten the staple twice on the interview day. The amount of matooke consumed per household per day varied from half a cluster (approximately $1.9 \mathrm{~kg}$ ) to a bunch (approximately $30 \mathrm{~kg})$. 


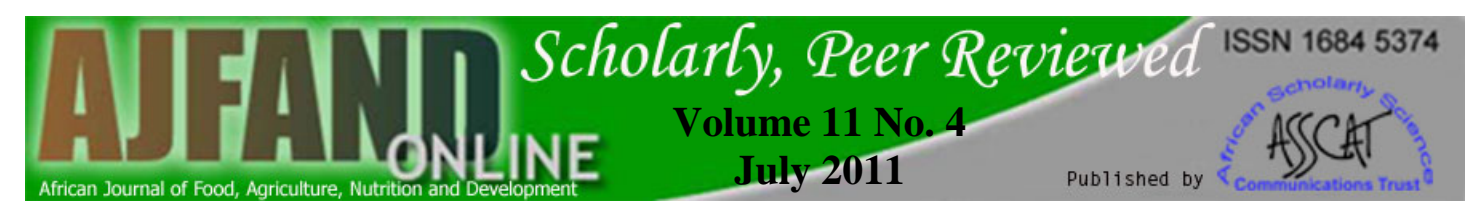

The majority of the respondents (88\%) consumed banana at least 3 times a week (Figure 1). Based on the fact that banana was widely consumed, it was considered a suitable food vehicle to improve nutrient intake of PLHIV.

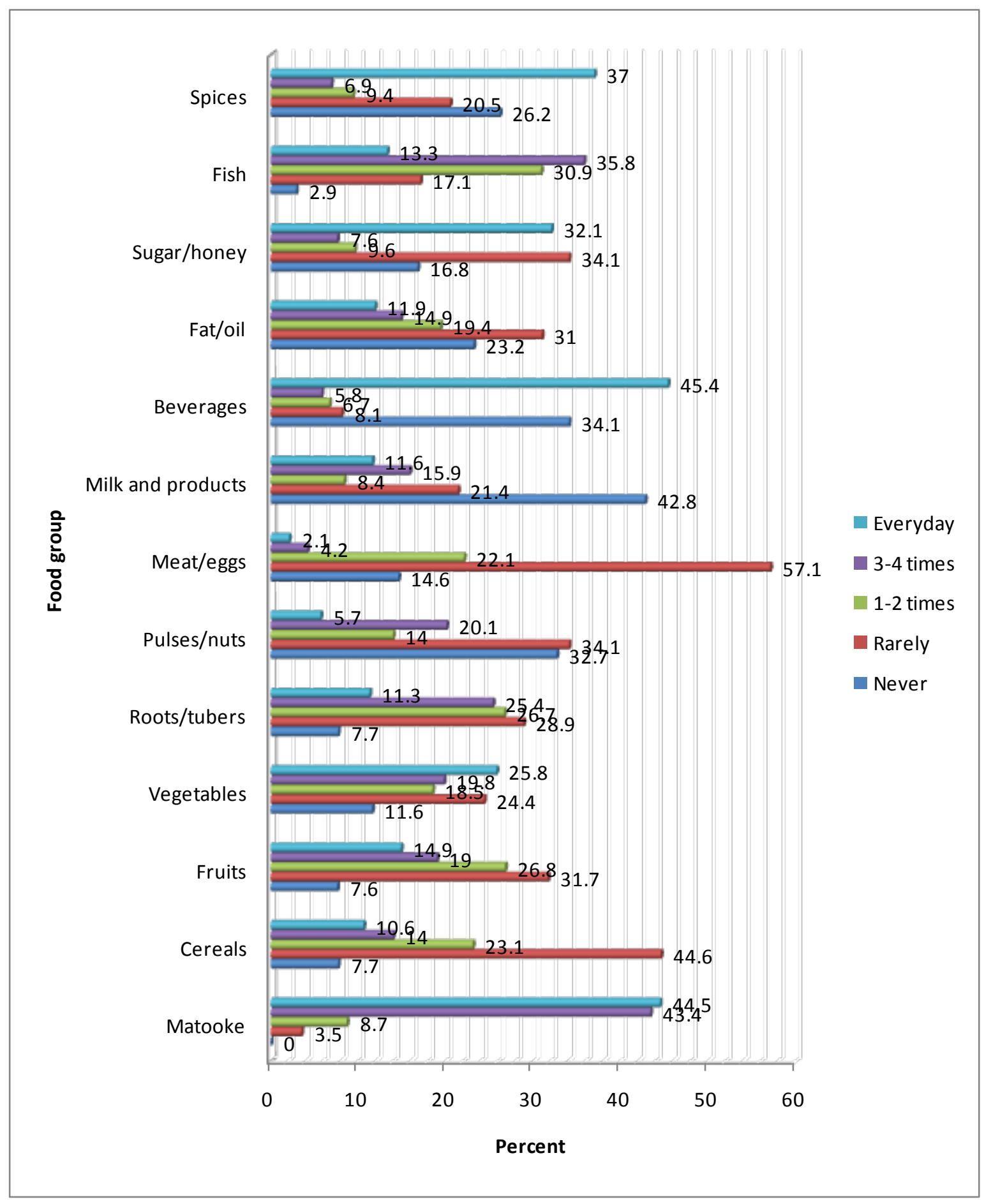

Figure 1: Percentage of average food group frequency compared to matooke in the households of PLHIV 
Other foods consumed by a significant proportion of the respondents at least three times a week included: fruits like tomatoes, mangoes and avocado (34\%), honey (40\%), spices like onions (44\%), and vegetables like doodo (Amaranthusdubius) and spider weed (Gynandropsis gynandra) locally called jjobyo (46\%),

Regarding dietary diversity score, only $18 \%$ of the respondents ate from all the food groups daily while $15 \%$ ate from all food groups on a 3-4 day basis. About $20 \%$ of the respondents never ate from all the food groups, $30 \%$ rarely ate from them and $17 \%$ ate 1-2 times from the food groups.

Matooke, was the most consumed banana type followed by ndiizi (ripening type) and then bogoya (Glos michel, ripening type) hence the cooking variety was chosen as a food vehicle. It was revealed that Kayinja and kisubi (juice types) were always sold for household income while gonja (roasting type) was rarely eaten in all households (Figure 2).

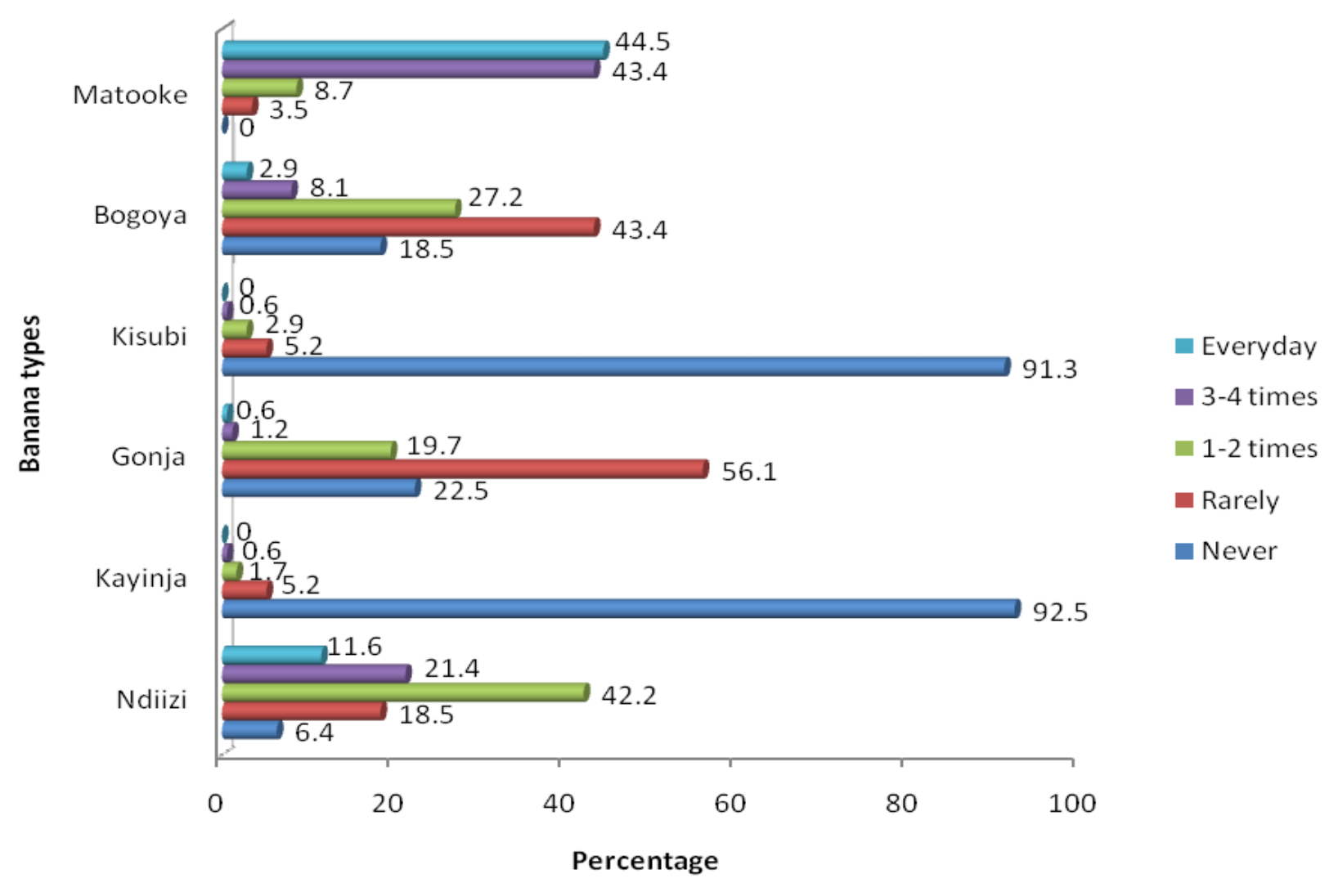

Figure 2: Frequency of banana consumption in the households of PLHIV

\section{Nutrient intake}

The average energy intake of PLHIV interviewed was $1594.7 \mathrm{kcal}$ on the weekday and $1676.2 \mathrm{kcal}$ on the weekend (Table 1). The caloric contribution of matooke to the dietary intake of PLHIV was found to be $611 \mathrm{kcal}$ (38\% of the total energy intake) on both the weekday and weekend (Table 2). 


\section{Nutrient composition of nutrient enhanced banana flour}

The energy density of the banana-soy blend was approximately $500 \mathrm{kcal} / 100 \mathrm{~g}$ (Table 3). The nutrient-analyzing USDA package (Table 4) showed that fat, protein, carbohydrate, and several micronutrient contents in the banana-soy blend were quite similar to those for the corn-soy blend, a food supplement often given to PLHIV [26].

\section{Acceptability and nutritional compositionof nutrient enhanced banana flour}

All the PLHIV who participated in the sensory evaluation of the product liked the banana-soy flour. The reasons given by the respondents for liking the nutrient enhanced banana flour included the following: Long satiety feeling (20\%); rich flavour (26.7\%); extra options of food eaten in the household (20\%); reduced consumption and running out of other foods (6.7\%); money that would be spent on cereals is saved (13.3\%); enhanced appetite (6.7\%) and helpful in situations of poor meals such as black tea (6.7\%). On average, the PLHIV consumed $67 \mathrm{~g}$ of the nutrient enhanced banana flour (both during the week and the weekend day). The amount consumed ranged from 15 to195g per day. The product was generally used to prepare beverages, porridge and to add to usual stews. The energy, iron, folic acid and calcium intake of the PLHIV who received the nutrient enhanced flour increased significantly (Table 5). However, the intake of these nutrients was still below RDA.

\section{DISCUSSION}

Baseline results showed that the average energy intake of the women was generally lower than their RDA by an average of $900 \mathrm{kcal}$ on both days of the interviews. Other nutrients whose intake were below the RDA by the respondents included vitamins $B_{1}$, $\mathrm{B}_{2}$, folate, calcium, iron, fat and, all essential in HIV/AIDS.

The fortified banana-soy blend was generally acceptable with hardly any behaviour change challenges because it merely supplemented the usual dietary practices in the households of PLHIV. Fortified-blended foods in the context of HIV/AIDS provide a valuable addition to the food basket because of their high energy and nutrient density, palatability, short cooking time and reduced burden for caregivers, enabling more frequent meals.

The fat, protein, carbohydrate, and several micronutrient contents in the banana-soy blend were quite similar to those for the corn-soy blend (Table 4), a food supplement often given to PLHIV [26]. Vitamins A, C, B 12 and E were, however, lower in the banana-soy blend compared to their RDA of $500 \mathrm{mcg}, 45 \mathrm{mg}, 2.4 \mathrm{mcg}$ and $5 \mathrm{mg}$, respectively. Generally, the fortificant used in this study had sufficient levels of most nutrients and could enable PLHIV to meet the RDA if a considerable amount of the nutrient-enhanced flour was consumed on daily basis. Nevertheless, a custom-made fortificant including all the essential micronutrients in the recommended levels in the banana-soy flour would address the nutritional gap in the households of PLHIV even better.

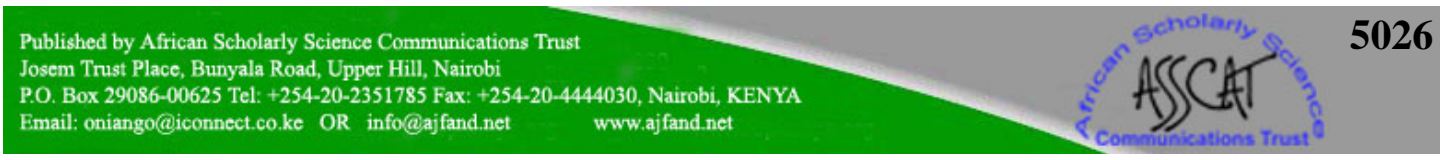




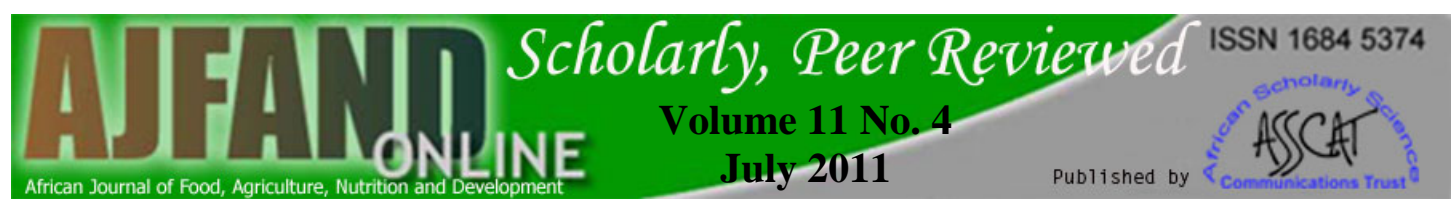

The PLHIV provided with nutrient enhanced banana flour recorded lower energy intake from other foods compared to baseline results. The product contributed $17 \%$ of total energy intake during the week and $15 \%$ over the weekend. The higher consumption of the nutrient-enhanced banana flour during weekdays may be attributed to the fact that there is less time for food preparations on week days and therefore, more households could have preferred to use the nutrient enhanced banana flour because it is easy-to-prepare. The energy intake of the repondents who consumed the product increased by $142.9 \mathrm{kcal}$ on the weekday and $391.8 \mathrm{kcal}$ on the weekend, representing $6 \%$ and $16 \%$ of RDA, respectively. Statistical analysis showed that supplementaion with nutrient enhanced banana flour led to a significant increase in dietary energy intake. The RDA of $2400 \mathrm{kcal}$ was, however, not met with a gap of $667 \mathrm{kcal}$ on the weekend and $879 \mathrm{kcal}$ on the weekday. An increase in the consumption of the nutrient enhanced banana flour above the recorded level of only 67g per day would be required to close the energy gap.

Studies in the past have showed that good nutrition can mitigate effects of HIV/AIDS and food-based strategies including fortification can address the problem of malnutrition [27, 28, 29]. Nutrition interventions also help to enhance the benefits of antiretroviral (ARV) drugs and may increase compliance with treatment regimes, both of which are essential to prolonging the lives of PLHIV [5]. Inspite of average consumption of only $67 \mathrm{~g}$ of the nutrient-enhanced banana flour by the study group from the 24 hour recall, there was remarkable increase in the intake of many nutrients. Therefore, nutrient-enhanced banana flour could lead to significant improvement of the nutritional and health status of PLHIV in Rakai District, if higher amounts are supplied.

\section{CONCLUSION}

The results show it is possible to produce an acceptable nutrient enriched product suitable for feeding PLHIV by blending banana flour made from pre-gelatinised matooke with flour made from roasted soybean and a multi-nutrient fortificant premix. Dietary incorporation of nutrient enhanced banana flour by PLHIV would help to improve their energy, protein and micronutrient intake. This would contribute to improved nutrition and health status in the long term and to slow progression of illness. The RDA for energy and all nutrients would be met by PLHIV if the target group increased the amount of banana product consumed and this could be achieved through increased supply of the product coupled with nutrition education and counselling of the target group.

\section{ACKNOWLEDGEMENTS}

Special thanks to the Lake Victoria Research Initiative (VicRes) for funding this project and to Rakai Health Science Project (RHSP), Rakai Agriculture Department and RACA for their cooperation. The PLHIV who participated in the study are highly appreciated. 


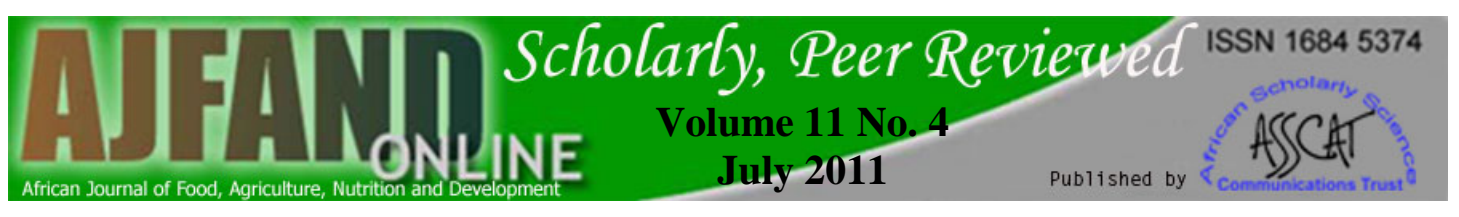

Table 1: Average nutrient intake by PLHIV in Rakai district, Uganda

\begin{tabular}{llllll}
\hline Nutrient & Weekend & \% of RDA & Weekday & \% of RDA & RDA \\
\hline Energy (kcal) & 1676.2 & 69.8 & 1594.7 & 66.4 & 2400 \\
Protein (\%) & 12.1 & $70 \%$ & 12.2 & 66 & $12-15$ \\
Fat (\%) & 14.1 & 47 & 18.1 & 60.3 & 30 \\
Vitamin A (mcg) & 975.8 & 195.2 & 975.3 & 195.1 & 500 \\
Vitamin C (mg) & 114.1 & 253.6 & 139.7 & 310.4 & 45 \\
Vitamin E (mg) & 8.4 & 168 & 7.0 & 140 & 5 \\
Vitamin B (mg) & 0.8 & 72.7 & 0.9 & 81.8 & 1.1 \\
Vitamin B $_{2}$ (mg) & 0.8 & 72.7 & 0.8 & 72.7 & 1.1 \\
Vitamin $B_{6}$ (mg) & 2.4 & 184.6 & 2.3 & 176.9 & 1.3 \\
Folate (mcg) & 249.6 & 62.4 & 206.0 & 51.5 & 400 \\
Calcium (mg) & 259.4 & 25.9 & 229.7 & 23 & 1000 \\
Zinc (mg) & 6.7 & 104.7 & 6.8 & 106.3 & 6.4 \\
Iron (mg) & 12.9 & 64.5 & 11.9 & 59.5 & $20 \mathrm{mg}$ \\
\hline
\end{tabular}

Table 2: Percentage of energy taken in from matooke in the diets of PLHIV in Rakai district, Uganda

\begin{tabular}{lll}
\hline Percentage of energyfrom matooke & Weekday & Weekend \\
\hline Kcal (average value) & 612.8 & 610.8 \\
Classification based on amount of energy from matooke & Frequency & Frequency \\
$<10 \%$ & 3 & 3 \\
$10-30 \%$ & 8 & 7 \\
$30-50 \%$ & 9 & 12 \\
$>50 \%$ & 10 & 9 \\
\hline
\end{tabular}




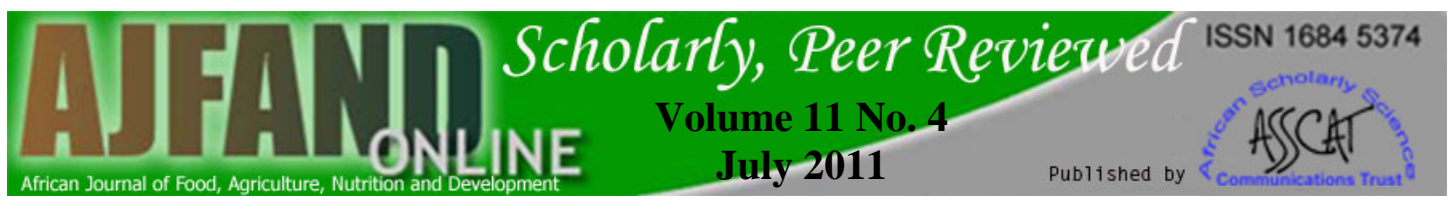

Table 3: Nutrient composition of banana-soy blend flour

\begin{tabular}{ll}
\hline Nutrient & $\begin{array}{l}\text { Amount in 100g } \\
\text { (mean } \pm \text { standard deviation) }\end{array}$ \\
\hline Energy (kcal) & $459.7 \pm 7.8$ \\
Carbohydrate (\%) & $50.70 \pm 4.81$ \\
Protein (\%) & $15.01 \pm 0.18$ \\
Fat (\%) & $6.02 \pm 0.13$ \\
Moisture (\%) & $8.31 \pm 0.19$ \\
Iron (mg) & $12.0 \pm 4.0$ \\
\hline
\end{tabular}




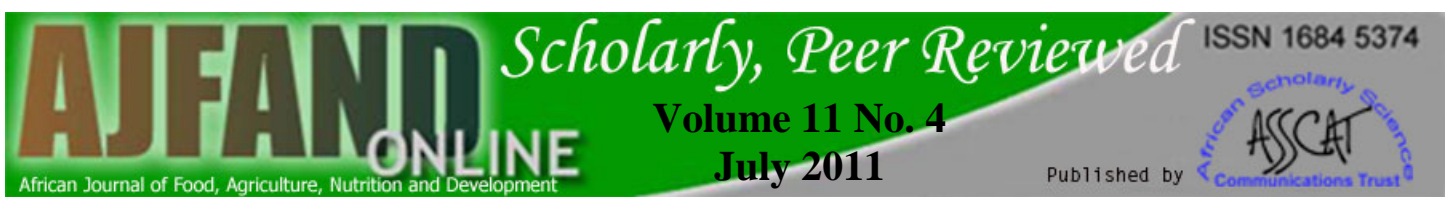

Table 4: Nutrient estimation of banana-soy blend compared to corn-soy blend (dry matter basis)

\begin{tabular}{|c|c|c|c|c|c|}
\hline Nutrient & $\begin{array}{l}\text { Banana, } \\
\text { dehydrated } \\
\text { (banana } \\
\text { powder) }\end{array}$ & $\begin{array}{l}\text { Soy flour, full-fat, } \\
\text { roasted, crude } \\
\text { protein basis }\end{array}$ & $\begin{array}{l}\text { Banana- } \\
\text { soy blend }\end{array}$ & $\begin{array}{l}\text { Fortified } \\
\text { banana-soy } \\
\text { blend }\end{array}$ & $\begin{array}{l}\text { Corn-soy } \\
\text { blend* }\end{array}$ \\
\hline Weight (g) & 61 & 39 & 100 & 100 & 100 \\
\hline Water (g) & 1.83 & 1.49 & 3.32 & 3.32 & 9.7 \\
\hline Energy (kcal) & 211 & 171 & 382 & 382 & 375.7 \\
\hline Protein (g) & 2.37 & 14.86 & 17.23 & 17.23 & 17.2 \\
\hline Total lipid (g) & 1.10 & 8.53 & 9.63 & 9.63 & 6.9 \\
\hline Carbohydrate (g) & 53.85 & 11.85 & 65.7 & 65.7 & 61.7 \\
\hline Calcium (mg) & 13 & 73 & 86 & 86 & 831 \\
\hline Iron (mg) & 0.70 & 2.27 & 2.97 & 3.5 & 17.49 \\
\hline Magnesium (mg) & 66 & 144 & 210 & 210 & 173.8 \\
\hline Phosphorous (mg) & 45 & 186 & 231 & 231 & 206 \\
\hline Potassium (mg) & 910 & 796 & 1706 & 1706 & 634 \\
\hline Sodium (mg) & 2 & 5 & 7 & 7 & 7.3 \\
\hline Zinc (mg) & 0.37 & 1.40 & 1.77 & 2.3 & 5.0 \\
\hline Copper (mg) & 0.239 & 0.866 & 1.105 & 1.105 & 0.9 \\
\hline Manganese (mg) & 0.350 & 0.810 & 1.16 & 1.16 & 0.7 \\
\hline Selenium (mcg) & 2.4 & 2.9 & 5.3 & 5.3 & 6 \\
\hline Vitamin C (mg) & 4.3 & 0 & 4.3 & 4.3 & 40 \\
\hline Vitamin $B_{1}(\mathrm{mg})$ & 0.110 & 0.161 & 0.271 & 0.4 & 0.53 \\
\hline Vitamin $\mathrm{B}_{2}(\mathrm{mg})$ & 0.146 & 0.367 & 0.513 & 0.6 & 0.48 \\
\hline Niacin (mg) & 1.708 & 1.282 & 2.99 & 4.2 & 6.23 \\
\hline Vitamin $\mathrm{B}_{6}(\mathrm{mg})$ & 0.268 & 0.137 & 0.405 & 0.5 & 0.5 \\
\hline Folate (mcg) & 9 & 89 & 98 & 120 & 300 \\
\hline Vitamin $B_{12}$ (mcg) & 0 & 0 & 0 & 0 & 1 \\
\hline Vitamin A (mcg) & 15.1 & 4.3 & 19.4 & 312.4 & 261.2 \\
\hline Vitamin E (mg) & 0.24 & & 0.24 & 0.24 & 8.7 \\
\hline Vitamin K (mcg) & 1.2 & & 1.2 & 1.2 & \\
\hline Choline (mg) & 12.0 & & 12 & 12 & \\
\hline
\end{tabular}

* Source: http://www.fas.usda.gov/excredits/pl480/commodities 


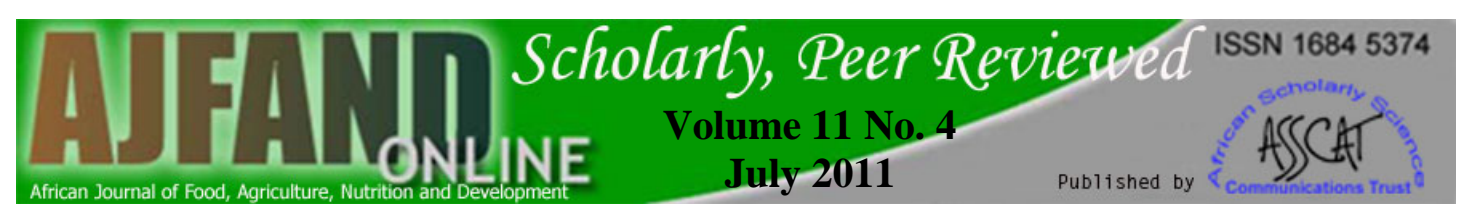

Table 5: Contribution of nutrient-enhanced banana flour to nutrient intake by 15 PLHIV in Rakai district, Uganda

\begin{tabular}{|c|c|c|c|c|c|c|c|c|}
\hline \multirow[t]{2}{*}{ Nutrient } & \multicolumn{4}{|c|}{ Weekday } & \multicolumn{4}{|c|}{ Weekend } \\
\hline & $\begin{array}{l}\text { Banana } \\
\text { product }\end{array}$ & $\begin{array}{l}\text { Other } \\
\text { foods }\end{array}$ & $\begin{array}{l}\text { Other foods + } \\
\text { banana product }\end{array}$ & $\begin{array}{l}\text { \% of } \\
\text { RDA }\end{array}$ & $\begin{array}{l}\text { Banana } \\
\text { product }\end{array}$ & $\begin{array}{l}\text { Other } \\
\text { foods }\end{array}$ & $\begin{array}{l}\text { Other foods + } \\
\text { banana product }\end{array}$ & $\begin{array}{l}\text { \% of } \\
\text { RDA }\end{array}$ \\
\hline Energy (kcal) & 256.9 & 1264.4 & 1521.3 & 63.4 & 257.85 & 1475.04 & 1732.89 & 73.2 \\
\hline Protein (\%) & 11.59 & 14.92 & 26.51 & 63 & 11.63 & 18.56 & 30.19 & 73 \\
\hline Fat (\%) & 6.48 & 16.61 & 23.09 & 76.7 & 6.5 & 21.42 & 27.92 & 93.1 \\
\hline Vitamin A (mcg) & 2101.16 & 601.61 & 2702.77 & $>100$ & 2108.97 & 700.05 & 2809.02 & $>100$ \\
\hline Vitamin C (mg) & 2.89 & 93.65 & 96.54 & $>100$ & 2.9 & 87.29 & 90.19 & $>100$ \\
\hline Vitamin E (mg) & 0.16 & 4.74 & 4.9 & 98 & 0.16 & 8.64 & 8.8 & $>100$ \\
\hline Vitamin $B_{1}$ (mg) & 0.27 & 0.6 & 0.87 & 79.1 & 0.27 & 0.55 & 0.82 & 74.5 \\
\hline Vitamin $B_{2}$ (mg) & 0.4 & 0.62 & 1.02 & 92.7 & 0.41 & 0.68 & 1.09 & 99.1 \\
\hline Vitamin $B_{6}(m g)$ & 2.2 & 1.86 & 2.2 & $>100$ & 0.34 & 1.96 & 2.3 & $>100$ \\
\hline Folate (mcg) & 80.7 & 162.29 & 242.99 & 60.7 & 81 & 196.8 & 277.8 & 69.5 \\
\hline Calcium (mg) & 57.84 & 250.07 & 307.91 & 30.8 & 58.05 & 242.74 & 300.79 & 30.1 \\
\hline Zinc (mg) & 1.55 & 5.39 & 6.94 & $>100$ & 1.55 & 7.51 & 9.06 & $>100$ \\
\hline Iron (mg) & 2.36 & 9.25 & 11.61 & 58.1 & 2.36 & 10.54 & 12.9 & 64.5 \\
\hline
\end{tabular}

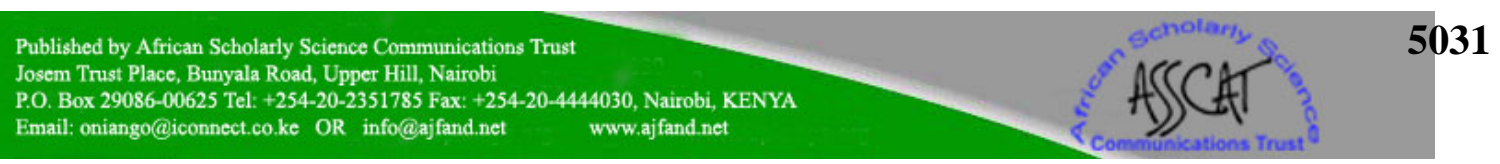




\section{REFERENCES}

1. UNAIDS. United Nations Programme for HIV/AIDS. Uganda: Country Situation Analysis. Joint United Nations Program on HIV/AIDS, USA. 2007. http://www.unaids.org/en/ (Accessed Jan 2009).

2. Serwadda D, Sewankambo NK and JW Carswell Slim Disease: A New Disease in Uganda and its Association with HTLVIII Infection. Lancet, 1985; 2:849-852.

3. Kikafunda JK and HK Namusoke Nutritional Status of HIV/AIDS Orphaned Children in Households Headed by the Elderly in Rakai District, South Western Uganda. African Journal of Food, Agriculture, Nutrition and Development. Volume 6, No.1, 2006. http://www.ajol.info/viewarticle.php?jid=110\&id=25257 (Accessed Feb 2009).

4. FANTA. Food and Nutrition Technical Assistance. HIV/AIDS: A Guide for Nutritional Care and Support. 2nd Edition. Washington D.C. Academy for Educational Development, 2004.

5. Friss H and KF Michaelsen"Micronutrients and HIV Infection: A Review," European Journal of Clinical Nutrition, 1998; 52:157-163.

6. Tang AM and E Smit Selected vitamins in HIV infection: A review. AIDS Patient Care STDS, 1998;12(4): 263-73.

7. World Bank. HIV/AIDS, Nutrition and Food Security: What We Can Do. A Synthesis of International Guidance. The international Bank for Reconstruction and Development. Washington DC. USA.2007. www.worldbank.org (Accessed March 2009).

8. WFP. World Food Programme. Food Assistance in the Context of HIV: Ration Design Guide. Planning a Food Ration for a Population that is Affected by HIV. Rome, Italy, 2008.

http://www.wfp.org/food_aid/doc/Ration_Design_Guide_2008.pdf (Accessed March 2009).

9. WHO and FAO. World Health Organization and Food and Agricultural Organization. Guidelines on Food Fortification with Micronutrients. World Health Organization. Geneva, Switzerland. Food and Agriculture Organization, Rome, Italy, 2006: 24-30.

10. USAID. United States Agency for International Development. Fortification Basics: Choosing A Vehicle. The USAID Micronutrient Programme, 1999. http://www.mostproject.org/Updates_Feb05/Vehicles.pdf (Accessed Jan 2008). 
11. Kiggundu A Uganda Develops Capacity for Agricultural Biotechnology at National Agricultural Research Laboratories Institute, Kawanda. Biovision, Newsletter. Vol. 3. ARENET. Republic of Uganda, 2006. www.arenet.or.ug (Accessed Feb 2008)

12. Muyonga JH Production and Evaluation of Precooked Dehydrated Unripe Banana Slices. African Crop Science Journal, 2000; 1(1): 93-98.

13. Muranga FI, Sampath H, Marlett JH and JM Ntambi Impact of Processing Technique on the Apparent Bioavailability of Cooking Banana (Matooke) Starch. African Journal of Biochemistry Research, 2007; 1(5): 72-77.

14. Muranga F I Composition and Physicochemical Characteristics of Starches of Different Banana Varieties. PhD Thesis, Makerere University, Kampala, Uganda, 1998: 1-13

15. Muyonga JH, Ramteke RS and WE Eipeson Predehydration steaming changes physicochemical properties of unripe banana flour. Journal of Food Processing and Preservation, 2001; 25(1): 35-47.

16. UBOS. Uganda Bureau of Statistics. Uganda Population and Housing Census: Rakai District Report. Uganda Bureau of Statistics, Kampala, Uganda, 2002. www.ubos.com (Accessed Jan 2008).

17. Gibson RS and EL FergusonAn Interactive 24 Hour Recall for Assessing the Adequacy of Iron and Zinc Intakes in Developing Countries. USAID and ILSI. U.S.A., 1999.

18. Bryan FJ The Design and Analysis of Research Studies. University of Otogo. Cambridge University Press, 1992.

19. FANTA. Food and Nutrition Technical Assistance. Household Dietary Diversity Score (HDDS) for Measurement of Household Food Access: Indicator Guide. Version 2. Food and Nutrition Technical Assistance, 2006. http://www.fantaproject.org (Accessed Jan 2008).

20. Berk Z Technology of Production of Edible Flours and Protein Products from Soybeans. FAO Agricultural Service Bulletin No. 97, 24 Rome, Italy, 1992.

21. Osman MA Effect of Different Processing Methods, on Nutrient Composition, Antinutrional Factors, and in vitro Protein Digestibility of Dolichos Lablab Bean [Lablab purpuresus (L) Sweet]. Pakistan Journal of Nutrition, 2007; 6(4): 299-303.

22. Wagner $\mathbf{J}$ and TL Stanton Formulating Rations with the Pearson Square. Colorado State University. 2008; 1: 618. http://www.ext.colostate.edu/PUBS/LIVESTK/01618.html (Accessed March 2009). 
23. AOAC. Association of Official Analyst Chemists Official Methods of Chemical Analysis of AOAC International. $16^{\text {th }}$ Edition. Volume 1. Gaithersburg, Maryland, USA, 1999.

24. Booil J Statistical Power in Randomized Intervention Studies with NonCompliance. The American Psychological Association. University of California, L. A., U.S.A., 2002; 7(2): 178-193

25. Rodríguez A, Prieto Y, Suárez A, Argüelles J, Mateo de Acosta G and M Rodríguez Computer Program Systems for Dietetic Calculations and Nutritional Recommendations. Rev CubanaAlimentos y Nutricion, 1987; 1(1): 47-53.

26. USDA/ FSA. United States Department of Agriculture and Farm Service Agency. Commodities Reference Guide: Corn-Soy Blend. Fact sheet. http://www.fas.usda.gov/excredits/pl480/commodities/ (Accessed August 2008)

27. Kadiyala $\mathbf{S}$ and $\mathbf{S}$ Gillespie Rethinking Food Aid to Fight AIDS: Food Consumption and Nutrition Division. IFPRI. FCND Discussion Paper No. 159. Washington D.C., U.S.A., 2003.

28. Byron E, Gillespie S and M Nangami Linking Nutritional Support with Treatment of People Living with HIV: Lessons Being Learned in Kenya. HIV, Livelihoods, Food and Nutrition Security. Findings from Renewal Research. Brief 2. International Food Policy Research. Washington D.C., U.S.A., 2007.

29. UNAIDS. HIV, Food Security and Nutrition: UNAIDS Policy Brief. WFP and WHO. Geneva, Switzerland, 2008. http://data.unaids.org/pub/Manual/2008/jc1515a_policybrief_nutrition_en.pdf (Accessed March 2009). 